\title{
UPAYA MENINGKATKAN KEAKTIFAN MAHASISWA DALAM MENGANALISIS VIDEO PEMBELAJARAN MELALUI STRATEGI PEMBELAJARAN WEBINAR
}

\author{
Evi Susilawati \\ Universitas Islam Sumatera Utara \\ evisusilawati@fkip.uisu.ac.id
}

\begin{abstract}
Abstrak: Penelitian ini bertujuan meningkatkan keaktifan mahasiswa dalam menganalisis video pembelajaran melalui strategi pembelajaran webinar. Penelitian ini merupakan penelitian tindakan kelas yang terdiri atas empat tahapan yaitu: (a) tahap perencanaan, (b) tahap pelaksanaan,(c) tahap observasi, (d) tahap analisis dan refleksi. Subjek dalam penelitian adalah mahasiswa semester VI Program Studi Pendidikan Guru Sekolah Dasar Fakultas Keguruan dan Ilmu Pendidikan Universitas Terbuka kelompok belajar Kota Medan pada tahun pelajaran 2020.1. Pelaksanaan penelitian tindakan kelas ini dilakukan pada matakuliah Pemantapan Kemampuan Mengajar dengan jumlah mahsiswa 12 orang. Teknik pengumpulan data pada data kuantitaif menggunakan instrumen tes kemampuan mahasiswa dalam menganalisis video pembelajaran dalam bentuk pilihan berganda, dan pada data kualitatif menggunakan hasil observasi keaktifan mahasiswa dalam menganilisis video pembelajaran dikelas webinar dan keaktifan dosen dalam mengajar dengan menggunakan strategi pembelajaran webinar. Hasil penelitian ini menunjukkan terdapat peningkatan keaktifan mahasiswa dalam menganalisis video pembelajaran dengan menggunakan strategi pembelajaran webinar.
\end{abstract}

Kata Kunci:Keaktifan Mahasiswa, VideoPembelajaran, Strategi Pembelajaran Webinar

\begin{abstract}
This study aims to increase student activity in analyzing instructional videos through a webinar strategy. This research is a classroom action research consisting of four stages namely: (a) the planning stage, (b) the implementation stage, $(c)$ the observation stage, $(d)$ the analysis and reflection stage. The subjects in the study were students of the 6th semester of the Primary School Teacher Education Study Program, Faculty of Teacher Training and Education, the Open University of the Medan City study group in the 2020.1. school year. The implementation of this classroom action research was carried out in the Teaching Ability Consolidation course with a total of 12 students. The technique of collecting data on quantitative data uses a student ability test instrument in analyzing learning videos in the form of multiple choices, and qualitative data uses the results of observations of student activeness in analyzing learning videos in the webinar class and lecturer activeness in teaching using webinar learning strategies. The results of this study indicate that there is an increase in student activeness in analyzing learning videos using webinar learning strategies.
\end{abstract}

Keywords: Student Activity, Learning Videos, Webinar Learning Strategies

\section{PENDAHULUAN}

Sejak mewabahnya Covid-19 dan adanya pemberlakuan kebijakan physical distancing telah merubah paradigma pembelajaran yang selama ini dilakukan secara konvensional melalui kegiatan tatap muka menjadi pembelajaran jarak jauh. Pembelajaran online ini menggunakan koneksi internet yang dapat dilakukan mahasiswa dirumah agar proses penjalaran Covid-19 dapat dicegah. Pembelajaran online di masa pandemi Covid-19 ini dapat diandalkan karena mahasiswa dapat sejumlah konten pembelajaran online dapat di akses alat teknologi informasi dan komunikasi bahkan dapat melalui ponsel pintar.

Perubahan paradigma pembelajaran yang begitu cepat ini mengharuskan dosen untuk mempunyai keterampilan dalam mendesain strategi pembelajaran dengan menggunakan pembelajaran online. Maraknya penggunaan pembelajaran online di masa pandemi Covid 19 ini mempunyai beberapa permasalahan seperti: (1) kurangnya interaksi yang intens antara dosen dan mahasiswa serta antara mahasiswa dengan mahasiswa, (2) perhatian mahasiswa hanya terkait materi pembelajaran online saja, (3) materi pembelajaran online biasanya didiskusikan dengan dosen melalui jaringan yang relevan seperti melalui email, grup what sapp, dan grup telegram yang membutuhkan waktu tertentu untuk merespon materi yang didiskusikan tersebut (Zhong, 2020). Selanjutnya Pace, Pettit, \& Barker (2020) mengemukakan bahwa pembelajaran online tidak dapat menarik minat mahasiswa. 
Bersosialisasi dan berkomunikasi secara ahtif melalui tatap muka dalam pembelajaran konvensional menjadi hilang dalam pembelajaran online dan semua mahasiswa hanya berkomunikasi dengan rekannya secara digital yang akhirnya mereka tidak pernah melihat teman-temanya secara langsung, untuk berbagi ide-ide, pengetahuan, dan informasi secara real-time (Adnan \& Kianat,2020).

Mencermati beberapa kelemahan tersebut diperlukan keprofesionalismean dosen untuk merancang strategi pembelajaran inovatif untuk menutupi kelemahan dari pembelajaran online karena bagaimanapun proses pembelajaran dimasa pandemi Covod-19 ini harus tetap dilaksanakan guna menyiapkan generasi penerus bangsa yang berkualitas dimasa mendatang. Untuk menyasati kelemahan dari pembelajaran online maka dilakukanlah pembelajaran online dengan menggunakan webinar.

\section{Strategi Pembelajaran Webinar}

Webinar diartikan sebagai alat komunikasi sinkron dalam melakukan kegiatan virtual yang dilakukan dalam waktu tertentu untuk memfasilitasi pengambilan keputusan tim, kerjasama tim, keterlibatan para anggota tim, dalam kegiatan pembelajaran maupun dalam dunia kerja (Wang \& Shu, 2008). Selanjutnya, Humphrey, Le Grand, \& Beard (2013) mengemukakan bahwa webinar merupakan jenis konferensi yang melibatkan seminar berbasis web yang disampaikan melalui internet. Pendapat senada dikemukakan oleh Harrison (2014) yang menyatakan bahwa webinar adalah jenis konferensi memungkinkan presenter dan peserta berkumpul secara online dari baik yang beasal dari kota besar maupun daerah dengan lokasi terpencil dengan menggunakan jaringan internet.

Webinar muncul pada awal tahun 1990an ketika munculnya penggunaan audio dan video dalam penggunaan web conferencing. Pada tahun 2000-an ketika ketersediaan akses internet berkecepatan tinggi menyebar luas dengan biaya penggunaan internet yang wajar dan banyaknya penyediaan perangkat lunak menggunakan kamera web maka banyak perusahaan yang membuat webinar dengan menggunakan video konferensi sehingga masyarakat dapat mengakses penyedia layanan video konferensi dengan harga yang terjangkau. Saat ini Ditengah pandemi Covid-19 penggunaan webinar oleh perusahaan maupun dalam dunia pendidikan secara global semakin meningkat. Khusus dalam kegiatan pembelajaran penggunaan webinar memerlukan kiat-kiat tertentu agar dapat mencapai tujuan pembelajaran yang telah ditentukan sehingga dosen memerlukan strategi pembelajaran yang cocok dengan karakteristik matakuliah dan materi yang akan disampaikannya. Susilawati (2017) mengemukakan bahwa strategi pembelajaran adalah kerangka konseptual yang mampu menggambarkan prosedur yang sistematis dalam menyelenggarakan pembelajaran dan pengalaman belajar untuk mencapai tujuan pembelajaran tertentu, dan berfungsi sebagai pedoman bagi guru dan/atau dosen dalam melaksanakan pembelajaran. Strategi pembelajaran webinar Strategi pembelajaran webinar merupakan strategi pembelajaran berisikan tentang tujuan pembelajaran yang telah ditentukan, prosedur sistematis menggunakan media, metode, dan peralatan audio dan video dalam penggunaan web conferencing dalam jaringan internet sehingga membentuk pengalaman belajar siswa dan/atau mahasiswa.

Beberapa hasil penelitian tentang penggunaan strategi pembelajaran webinar dalam kegiatan pembelajaran dikemukakan oleh Adnan \& Kianat (2020) yang mengemukakan bahwa strategi pembelajaran webinar efektif digunakan dalam kegiatan pembelajaran sepanjang ada jaringan internet dan akses bagi mahasiswa serta bagi dosen. Hasil penelitian Wang \& Shu (2008) juga menyatakan bahwa strategi pembelajaran webinar sangat efektif digunakan karena: (1) dapat memfasilitasi komunikasi antara mahasiswa dan dosen, memperkaya interaksi pembelajaran dalam lingkungan belajar online, (2) penyampaian pengetahuan konseptual mahasiswa yang difasilitasi dalam webinar mampu meningkatkan peran sosial mahasiswa dan memfasilitasi keaktifan dan interaksi sosial multi-level, (3) strategi pembelajaran webinar merupakan strategi pembelajaran yang mampu memperkuat siklus pembelajaran interaktif berbasis teknologi. Temuan Basilaia \& Kvavadze (2020) dalam penelitiannya menyimpulkan bahwa seperti pembelajaran konvensional, penggunaan strategi pembelajaran webinar terdapat interaksi yang memuaskan dalam pendidikan jarak jauh di antara mahasiswa serta dosen karena konten 
dalam strategi pembelajaran webinar dirancang dengan baik dan mutakhir, dosen berkomitmen, dan harus terlatih dengan keterampilan teknologi komunikasi informasi.

Mencermati hasil-hasil penelitian terkait dengan webinar, ternyata banyak keunggulan penggunaan strategi pembelajaran webinar dalam kegiatan pembelajaran. Penggunaan strategi pembelajaran tidak mengurangi keaktifan, komunikasi mahasiswa dalam kegiatan pembelajaran dan penyampaian pengetahuan konseptual mahasiswa. Sebagai strategi pembelajaran online, penggunaan strategi pembelajaran webinar dapat dipadupadankan dengan berbagai media pembelajaran salah satunya penggunaan video pembelajaran. Penggunaan video pembelajaran dapat membantu mahasiswa untuk dapat memecahkan masalah belajar. Untuk itu diperlukan kemampuan mahasiswa dalam menganalisis video pembelajaran.

\section{Video Pembelajaran}

Pembelajaran dengan menggunakan video tentunya memberikan pengalaman tersendiri bagi mahasiswa. Menurut Kay (2012) video diklasifikasikan dalam berbagai kategori yaitu: video pembelajaran, video materi pembelajaran online, video screen captures, video podcast dan video web broadcasts. Khusus dalam penggunaan video pembelajaran, Fahrurozi, Dwi. \& Cucuk (2017) mendefinisikan video pembelajaran sebagai media yang menyajikan pesan audio visual, bahasa, prosedur, aplikasi teori untuk membantu pemahaman mahasiswa suatu materi pembelajaran yang disajikan dosen.

Perkembangan teknologi komunikasi dan informasi memungkinkan video dapat diakses dengan lebih mudah, lebih cepat, dan lebih luas dengan berbagai platform dan berbagai perangkat baik milik mahasiswa maupun milik dosen. Dalam kegiatan pembelajaran online, penggunaan video memainkan peranan penting dalam memfasilitasi pembelajaran (Bates, 2015). Video pembelajaran yang merupakan media audio dan visual dan berisi materi pembelajaran yang dapat digunakan untuk mengirim pesan atau menerima pesan menjadi salah satu kontributor pada kegiatan pembelajaran online sebagai agen kuat yang menambah nilai dan meningkatkan kualitas pembelajaran online. Video pembelajaran mempunyai fungsi sebagai berikut: (a) berfungsi sebagai penarik perhatian yang mengarahkan konsentrasi mahasiswa pada materi yang disajikan, (b) berfungsi sebagai penuntut perilaku mahasiswa yang mana ketika mahasiswa belajar dengan menonton video, dapat menggugah emosi dan menuntun perilaku mereka untuk berperilaku lebih baik lagi, (c) berfungsi kognitif yang mana dengan menonton video dapat mempercepat pencapaian tujuan pembelajaran untuk memahami dan mengingat pesan atau informasi yang terkandung dalam gambar atau lambang yang terdapat dalam video, (d) berfungsi sebagai kompensatoris yang mana video dapat memberikan konteks materi kepada mahasiswa yang mempunyai kemampuan lemah dalam mengorganisasikan dan mengingat kembali informasi yang telah diperoleh dalam kegiatan pembelajaran. Berdasarkan keempat manfaat penggunaan vidoe pembelajaran di atas dapat disimpulkan bahwa penggunaan video pembelajaran mampu membantu mahasiswa dalam mengingat, menangkap suatu pesan suatu pesan sehingga mahasiswa menjadi mudah dalam menerima dan memahami materi-materi yang disampaikan.

Selain fungsi video pembelajaran seperti yang telah diuraikan di atas, pengguaan video pembelajaran mempunyai manfaat sebagai berikut: (a) proses pembelajaran lebih cepat dipahami oleh mahasiswa, (b) dosen lebih mudah menyampaikan materi, (c) menumbuhkan keaktifan mahasiswa dalam belajar, (d) memotivasi mahasiswa, (e) membantu mahasiswa agar lebih mudah dalam memaknai pesan yang disampaikan dosen agar lebih jelas sehingga dapat dipahami oleh mahasiswa dan memungkinkan terjadinya penguasaan dan pencapaian tujuan tujuan pembelajaran, (f) sebagai bahan pelengkap materi, (g) memberikan informasi yang lebih canggih dan cepat, (h) memberikan informasi. Kebermanfaatan video pembelajaran tersebut tentunya dapat digunakan pada pembelajaran matakuliah Pemantapan Kemampuan Mengajar.

\section{Keaktifan Mahasiswa Dalam Menganalisis Video Pembelajaran Pada MataKuliah Pemantapan Kemampuan Mengajar}

Matakuliah Pemantapan Kemampuan Mengajar merupakan salah satu matakuliah yang diberikan pada mahasiswa yang menempuh Program Studi Pendidikan Guru Sekolah Dasar Fakultas Keguruan dan Ilmu 
Pendidikan di Universitas Terbuka. Matakuliah ini diberikan kepada mahasiswa untuk memberikan kesempatan kepada mereka dalam menerapkan pengetahuan, keterampilan, serta memodelkan perilaku-perilaku yang diperoleh dalam berbagai matakuliah. Disadari bahwa mahasiswa yang menempuh Program Studi Pendidikan Guru Sekolah Dasar harus diberikan bekal keprofesionalismean dalam mengajar. Hal ini penting dilakukan karena profesi mengajar bukanlah pekerjaan yang mudah dilakukan. Kegiatan mengajar bukanlah sekadar kegiatan rutinitas keseharuan seorang guru. Dalam kegiatan mengajar terkandung kemampuan menganalisis kebutuhan siswa, mengambil keputusan apa yang harusdikaukan oleh seorang guru, merancang pembelajaran yang efektif dan efisien, mengaktifkan siswa, mengevaluasi hasil belajar, serta menyempurnakan pembelajaran berikutnya agar lebih efektif dan dapat meningkatkan hasil belajar siswa. Mengingat begitu pentingnya matakuliah ini diberikan kepada mahasiswa, maka diperlukan kemampuan mahasiswa sebagai calon guru SD dalam menganalisis karakteristik dan kebutuhan belajar siswa serta situasi pembelajaran di SD. Sugiyono (2015) memberiksn pengertian analisis sebagai sebuah kegiatan dalam mencari suatu pola atau cara berpikir yang berkaitan dengan pengujian secara sistematis terhadap sesuatu untuk menentukan bagian, hubungan antar bagian dan hubungannya dengan keseluruhan. Kegiatan analisis dalam kegiatan pembelajaran matakuliah Pemantapan Kemampuan Mengajar yang dilakukan mahasiswa bertujuan untuk menguraikan suatu masalah atau fokus kajian yang terkait dengan karakteristik dan kebutuhan belajar siswa serta situasi pembelajaran di SD sehingga menjadi bagian-bagian atau tatanan kajian yang bisa diuraikan pemecahan permasahannya. Kegiatan analisis pembelajaran ini biasanya dilakukan dengan melakukan observasi ke sekolah. Sehubungan pada tahun pembelajaran 2020.1. kebijakan pembelajaran di Universitas Terbuka menggunakan kegiatan pembelajaran online maka kegiatan menganalisis karakteristik dan kebutuhan belajar siswa serta situasi pembelajaran di SD dilakukan dengan menggunakan video pembelajaran yang diakses dari laman gurupintar.ut.ac.id. Melalui laman tersebut, mahasiswa diberikan beberapa video untuk dianalisis yang terkait dengan kelemahan dan kelebihan pembelajaran serta hal-hal yang unik yang terdapat dalam video pembelajaran. Sebagaimana dipaparkan pada uraian terdahulu bahwa sehubungan dengan mewabahnya Covid-19 maka pada tahun pembelajaran 2020.1. kebijakan pembelajaran di Universitas Terbuka menggunakan kegiatan pembelajaran online sehingga kegiatan pembelajaran pada matakuliah Pemantapan Kemampuan Mengajar dilakukan secara online dengan menggunakan webinar. Meskipun menggunakan pembelajaran webinar, keaktifan mahasiswa harus menjadi perhatian utama. Keaktifan belajar mahasiswa merupakan hal yang penting bagi keberhasilan proses pembelajaran. Keaktifan dimaknai sebagai kegiatan yang bersifat fisik maupun mental yang terkait dengan perbuatan dan berfikir sebagai suatu rangkaian yang tidak dapat dipisahkan. Kegiatan tersebut dilaksanakan baik secara fisik dan psikis. Keaktifan mahasiswa selama proses pembelajaran matakuliah Pemantapan Kemampuan Mengajar merupakan salah satu indikator adanya keinginan mahasiswa untuk memahami materi matakuliah Pemantapan Kemampuan Mengajar yang salah satu materinya adalah kegiatan analisisis video pembelajaran. Keaktifan mahasiswa dalam menganalisis video pembelajaran dapat dilihat dari karakteristik sebagai berikut: (1) mengajukan pertanyaan dan pendapat baik kepada dosen dan sesama teman terkait video pembelajaran yang dianalisis, (2) menjawab pertanyaan dosen video pembelajaran yang dianalisis, (3) bekerjasama dengan mahasiswa lain, (4) bertanggung jawab terhadap penyelesaian tugas analisis video pembelajaran.

\section{METODE}

Penelitian ini berjenis penelitian tindakan kelas (action research). Penelitian tindakan kelas diartikan penelitian yang dilakukan peneliti di kelas yang bertujuan untuk mengatasi masalah dalam praktik pembelajaran di kelas (Susilawati, 2020). Model penelitian tindakan kelas terdiri atas empat tahapan sebagai berikut: (1) tahap perencanaan merupakan tahapan penelitian langkah-langkah: (a) tahap penyusunan perencanaan penelitian, (b) refleksi awal kegiatan pembelajaran matakuliah Pemantapan Kemampuan Mengajar, (c) mengidentifikasi berbagai permasalahan pembelajaran yang ditemukan, (d) penyusunan strategi pembelajaran yang sesuai dengan permasalahan pembelajaran yang ditemukan, (e) 
membuat rancangan pelaksanaan pembelajaran, (f) penyusunan lembar pengamatan (g) membuat lembar instrumen; (2) tahap pelaksanaan dengan langkah-langkah kegiatan penelitian sebagai berikut: (a) penerapan rancangan kegiatan strategi pembelajaran webinar, (b) mengikuti langkah-langkah strategi pembelajaran webinar pembelajaran dan prosedur penelitian dengan baik; (3) tahap pengamatan dengan langkah-langkah kegiatan penelitian sebagai berikut : (a) mengamati aktifitas dosen dalam pembelajaran melaksanakan strategi pembelajaran webinar, (b) mengamati aktifitas mahasiswa dalam kegiatan pembelajaran menggunakan strategi pembelajaran webinar, (4) tahap analisis dan refleksi dengan langkah-langkah kegiatan penelitian sebagai berikut: (a) analisis dan refleksi terhadap lembar pengamatan aktifitas dosen dalam melaksanakan strategi pembelajaran webinar, (b) analisis dan refleksi terhadap lembar pengamatan aktifitas mahasiswa dalam mengikuti strategi pembelajaran webinar, (c) analisis dan refleksi terhadap tes hasil belajar mahasiswa pada materi analisis video pembelajaran. Langkah-langkah kegiatan penggunaan strategi pembelajaran webinar terhadap dalam meningkatkan keaktifan mahasiswa dalam menganalisis video pembelajaran dapat dilihat pada Gambar 1 . berikut ini:

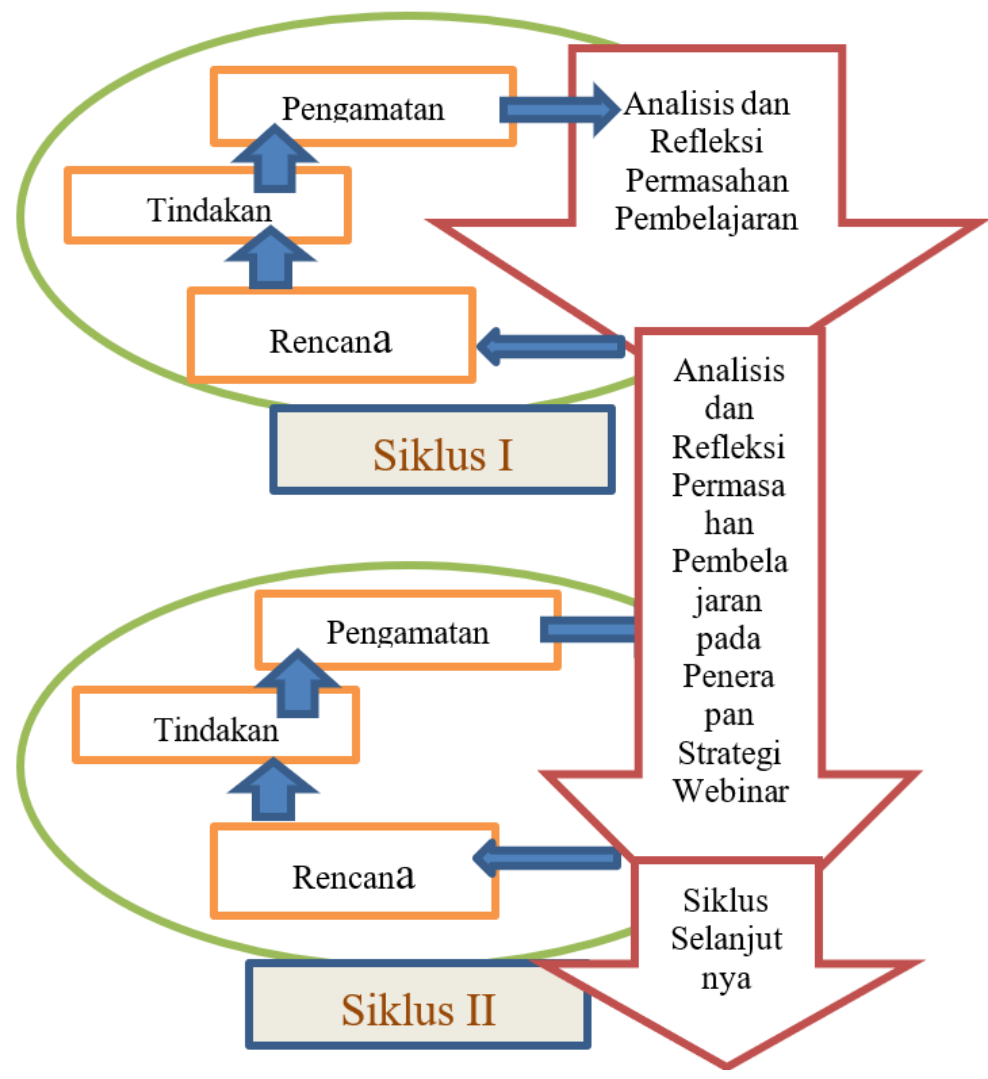

Gambar 1: Langkah-langkah kegiatan Penelitian pada Kemampuan Mahasiswa dalam Menganalisis Video Pembelajaran Dengan Menggunakan Strategi Webinar

Subjek dalam penelitian ini adalah mahasiswa semester VI Program Studi Pendidikan Guru Sekolah Dasar (PGSD) Fakultas Keguruan dan Ilmu Pendidikan (FKIP) Universitas Terbuka kelompok belajar Kota Medan. Pelaksanaan penelitian tindakan kelas ini dilakukan pada matakuliah Pemantapan Kemampuan Mengajar dengan jumlah 12 orang. Peran dan posisi peneliti dalam penelitian ini sebagai dosen yang bertindak langsung melakukan kegiatan peembelajaran matakuliah Pemantapan Kemampuan Mengajar yang dibantu oleh dua orang observer. Kegiatan penelitian ini dilakukan pada semester genap tahun pealajaran 2020.1

Penggunaan teknik pengumpulan data pada penelitian ini terdiri dari data kuantitatif dan kualitatif yang mana data kuantitaif 
diperoleh melalui instrumen tes anlisis video pembelajaran mahasiswa pada matakuliah Pemantapan Kemampuan Mengajar dalam bentuk pilihan berganda, sementara data kualitatif diperoleh berdasarkan hasil pengamatan melalui lembar aktifitas dosen dalam melaksanakan strategi pembelajaran webinar dan hasil pengamatan terhadap lembar aktifitas mahasiswa dalam mengikuti strategi pembelajaran webinar. Indikator keberhasilan pada penggunaan strategi pembelajaran webinar terhadap aktifitas mahasiswa dalam menganalisis video pembelajaran berada pada rentang skor 75\%-100\%. Untuk aktifitas dosen pada penggunaan strategi pembelajaran webinar pembelajaran berada pada rentang skor $85 \%$ $100 \%$. Selanjutnya untuk tes hasil belajar mahasiswa terhadap menganalisis video berada pada rentang skor $70 \%-100 \%$.

\section{HASIL DAN PEMBAHASAN \\ Aktivitas Mengajar Dosen Dalam Upaya Meningkatkan Kemampuan Mahasiswa dalam Menganalisis Video Pembelajaran Dengan Menggunakan Strategi Webinar}

Aktifitas mengajar dosen dalam upaya meningkatkan kemampuan mahasiswa dalam menganalisis video pembelajaran pada matakuliah Pemantapan Kemampuan Mengajar melalui penggunaan strategi pembelajan webinar dengan menggunakan lembar pengamatan diperoleh data yang dapat dilihat pada Tabel 1 berikut ini:

Tabel 1. Aktivitas Mengajar Dosen Dalam Upaya Meningkatkan Kemampuan Mahasiswa dalam Menganalisis Video Pembelajaran Dengan Menggunakan Strategi Webinar

\begin{tabular}{llcc}
\hline \multicolumn{1}{c}{$\begin{array}{c}\text { Lembar } \\
\text { Observasi }\end{array}$} & Aktifitas dosen dalam menggunakan Strategi Webinar & $\begin{array}{c}\text { Siklus } \\
\mathbf{1}\end{array}$ & $\begin{array}{c}\text { Siklus } \\
\mathbf{2}\end{array}$ \\
\hline Indikator 1 & $\begin{array}{l}\text { Mengelola ruang dan fasilitas belajar dengan menggunakan } \\
\text { Strategi Webinar }\end{array}$ & 68 & 86 \\
\hline Indikator 2 & $\begin{array}{l}\text { Melaksanakan kegiatan perbaikan pembelajaran pelaksanaan } \\
\text { Strategi Webinar }\end{array}$ & 68.5 & 85.5 \\
\hline Indikator 3 & Mengelola interaksi kelas webinar & 70 & 88 \\
\hline Indikator 4 & $\begin{array}{l}\text { Bersikap terbuka dan luwes serta membantu mengembangkan } \\
\text { sikap mahasiswa dalam pelaksanaan Strategi Webinar }\end{array}$ & 78 & 87 \\
\hline Indikator 5 & Mendemonstrasikan kemampuan TIK & 76 & 86 \\
\hline Indikator 6 & $\begin{array}{l}\text { Melaksanakan penilaian hasil belajar Pwnggunaan Strategi } \\
\text { Webinar }\end{array}$ & 69 & 86.5 \\
\hline Rata-Rata Keaktifan Dosen dari Siklus 1 ke Siklus 2 & 72 & 86 \\
\hline Persentase Kenaikan Keaktifan Dosen dari Siklus 1 ke Siklus 2 & $21.6 \%$
\end{tabular}

Berdasarkan pada Tabel 1 dapat dilihat adanya peningkatan pada keaktifan dosen dalam menggunakan strategi pembelajaran webinar pada siklus pertama dengan rata-rata perolehan skor 72, dan pada siklus kedua menujukkan rata-rata perolehan skor 86. Merujuk pada perolehan skor tersebut, terjadi peningkatan aktifitas mengajar dosen dalam menggunakan strategi pembelajaran webinar dari siklus I ke siklus II sebesar $21.6 \%$. Perolehan nilai keaktifan dosen pada siklus kedua ini telah mencapai indikator keberhasilan dalam penelitian ini yang berada pada rentang skor
85\%-100\% sehingga penelitain ini berhenti pada siklus kedua.

\section{Aktivitas Mahsiswa Dalam Menganalisis Video Pembelajaran Dengan Menggunakan Strategi Webinar}

Aktifitas mahasiswa dalam menganalisis video pembelajaran pada matakuliah Pemantapan Kemampuan Mengajar melalui penggunaan strategi pembelajan webinar dengan menggunakan lembar pengamatan diperoleh data yang dapat dilihat pada Tabel 2 berikut ini:

Tabel 2. Aktivitas Mahasiswa dalam Menganalisis Video Pembelajaran Dengan Menggunakan 


\begin{tabular}{clcc}
\multicolumn{1}{c}{ Strategi } & Webinar & & \\
\hline $\begin{array}{c}\text { Lembar } \\
\text { Observasi }\end{array}$ & $\begin{array}{c}\text { Aktifitas mahasiswa dalam menganalisis video } \\
\text { pembelajaran menggunakan Strategi Webinar }\end{array}$ & $\begin{array}{c}\text { Siklus } \\
\mathbf{1}\end{array}$ & $\begin{array}{c}\text { Siklus } \\
\mathbf{2}\end{array}$ \\
\hline Indikator 1 & $\begin{array}{l}\text { Mengajukan pertanyaan dan pendapat baik kepada dosen } \\
\text { dan sesama teman terkait video pembelajaran yang dianalisis }\end{array}$ & 63 & 87.48 \\
\hline Indikator 2 & $\begin{array}{l}\text { Menjawab pertanyaan dosen video pembelajaran yang } \\
\text { dianalisis }\end{array}$ & 67 & 87.58 \\
\hline Indikator 3 & Bekerjasama dengan mahasiswa lain & 67 & 86.4 \\
\hline Indikator 4 & $\begin{array}{l}\text { Bertanggung jawab terhadap penyelesaian tugas analisis } \\
\text { video pembelajaran }\end{array}$ & 69 & 88 \\
\hline Rata-Rata Keaktifan Mahasiswa dari Siklus 1 ke Siklus 2 & 66.5 & 87.37 \\
\hline Persentase Kenaikan Keaktifan Mahasiswa dari Siklus 1 ke Siklus 2 & $20.04 \%$
\end{tabular}

Merujuk pada Tabel 2 dapat dilihat adanya peningkatan pada keaktifan mahasiswa dalam menganalisis video pembelajaran dengan menggunakan strategi pembelajaran webinar pada siklus pertama dengan rata-rata perolehan skor 66,5 dan pada siklus kedua menujukkan rata-rata perolehan skor 87,37 . Merujuk pada perolehan skor tersebut, terjadi peningkatan aktifitas mahasiswa dalam menganalisis video pembelajaran dengan menggunakan strategi pembelajaran webinar. Mencermati pada perolehan skor pada Tabel 2, terjadi peningkatan aktifitas mahasiswa dalam menganalisis video pembelajaran dengan menggunakan strategi pembelajaran webinar.dari siklus I ke siklus II sebesar 20.4\% Perolehan nilai keaktifan mahasiswa pada siklus kedua ini telah mencapai indikator keberhasilan dalam penelitian ini yang berada pada rentang skor $75 \%-100 \%$ sehingga penelitain ini berhenti pada siklus kedua.

Kemampuam Mahsiswa Dalam Menganalisis Video Pembelajaran Dengan Menggunakan Strategi Webinar

Kemampuan mahasiswa dalam menganalisis video pembelajaran pada matakuliah Pemantapan Kemampuan Mengajar melalui penggunaan strategi pembelajan webinar dengan menggunakan tes hasil belajar diperoleh data yang dapat dilihat pada Tabel 3 berikut ini:

Tabel 3. Kemampuan Mahasiswa dalam Menganalisis Video Pembelajaran Dengan Menggunakan Strategi Webinar

\begin{tabular}{|c|c|c|c|}
\hline $\begin{array}{c}\text { Lembar } \\
\text { Observasi }\end{array}$ & $\begin{array}{l}\text { Kemampuan mahasiswa dalam menganalisis video } \\
\text { pembelajaran menggunakan Strategi Webinar }\end{array}$ & $\begin{array}{c}\text { Siklus } \\
1\end{array}$ & $\begin{array}{l}\text { Siklus } \\
\quad 2\end{array}$ \\
\hline Indikator 1 & $\begin{array}{l}\text { Mengajukan pertanyaan dan pendapat baik kepada dosen } \\
\text { dan sesama teman terkait video pembelajaran yang } \\
\text { dianalisis }\end{array}$ & 65 & 87.51 \\
\hline Indikator 2 & $\begin{array}{l}\text { Menjawab pertanyaan dosen video pembelajaran yang } \\
\text { dianalisis }\end{array}$ & 68,23 & 88.62 \\
\hline \multicolumn{2}{|c|}{ Rata-Rata Mahasiswa Mahasiswa dari Siklus 1 ke Siklus 2} & 6.67 & 88.65 \\
\hline \multicolumn{2}{|c|}{$\begin{array}{l}\text { Persentase Kenaikan Kemampuan Mahasiswa Dalam Menganalisis } \\
\text { Video Pembelajaran dari Siklus } 1 \text { ke Siklus } 2\end{array}$} & \multicolumn{2}{|c|}{$33.98 \%$} \\
\hline
\end{tabular}

Melihat pada perolehan skor pada Tabel 3, terjadi peningkatan kemampuan mahasiswa mahasiswa dalam menganalisis video pembelajaran dengan menggunakan strategi pembelajaran webinar.dari siklus I ke siklus II sebesar $33.98 \%$ Perolehan nilai keaktifan mahasiswa pada siklus kedua ini telah mencapai indikator keberhasilan dalam penelitian ini yang berada pada rentang skor $70 \%-100 \%$ sehingga penelitain ini berhenti pada siklus kedua.

Mencermati hasil temuan-temuan penelitian di atas dapat dipahami bahwa di masa 
pandemi Covid-19 ini penggunaan strategi pembelajaran dengan menggunakan pembelajaran online semakin meningkat. Penggunaan media pembelajaran online yang dipadupadankan dengan strategi pembelajaran sangat di butuhkan bagi penigkatan aktifitas belajar mahasiswa. Strategi pembelajaran webinar yang dipadupadankan dengan penggunaan video pembelajaran telah meningkatkan aktifitas belajar mahasiswa dan kemampuan mahasiswa dalam menganalisis materi pembelajaran yang diberikan dosen. Penggunaan strategi pembelajaran webinar terbukti telah mendorong keaktifan mahasiswa dalam mengajukan pertanyaan dan pendapat baik kepada dosen dan sesama teman terkait video pembelajaran yang dianalisis, menjawab pertanyaan dosen video pembelajaran yang dianalisis, bekerjasama dengan mahasiswa lain, dan mahasiswa menyelesaikan tugas yang diberikan dosen dengan tepat waktu. Hal ini menunjukkan bahwa meskipun mahasiswa terhubung dengan jarak yang berbeda tetapi tetap bisa melaksanakan kegiatan tatap muka secara online, diskusi secara bersama-sama menggunakan internet. Temuan penelitian ini sejalan dengan hasil penelitian yang dilakukan oleh (Wang \& Shu, 2008) yang menyatakan bahwa webinar sebagai alat komunikasi sinkron dalam melakukan kegiatan virtual yang dilakukan dalam waktu tertentu untuk memfasilitasi pengambilan keputusan tim, kerjasama tim, keterlibatan para anggota tim, dalam kegiatan pembelajaran maupun dalam dunia kerja.

Penggunaan strategi pembelajaran webinar juga terbukti telah menigkatkan aktifitas mengajar dosen. Berdasarkan hasil temuan penelitian ini ditemukan bahwa terjadi peningkatan aktifitas dosen dalam mengelola ruang dan fasilitas belajar, melaksanakan kegiatan perbaikan pembelajaran, mengelola interaksi kelas, bahkan dosen tetap berkomunikasi dengan baik ramah, bersikap terbuka dan luwes sehingga mahasiswa tetap merasa nyaman belajar dengan menggunakan strategi pembelajaran webinar. Hasil temuan penelitian ini mendukung temuan penelitian yang dilakukan oleh Temuan penelitian ini juga mendukung hasil penelitian yang dilakukan oleh Basilaia \& Kvavadze (2020) yang mengemukakan bahwa penggunaan strategi pembelajaran webinar terdapat interaksi yang memuaskan dalam pendidikan jarak jauh di antara mahasiswa serta dosen karena konten dalam strategi pembelajaran webinar dirancang dengan baik dan mutakhir, dosen berkomitmen, dan harus terlatih dengan keterampilan teknologi komunikasi informasi.

Mencermati hasil-hasil penelitian ternyata banyak keunggulan penggunaan strategi pembelajaran webinar dalam kegiatan pembelajaran. Penggunaan strategi pembelajaran tidak mengurangi keaktifan, komunikasi mahasiswa dalam kegiatan pembelajaran dan penyampaian pengetahuan konseptual mahasiswa. Sebagai strategi pembelajaran online, penggunaan strategi pembelajaran webinar dapat dipadupadankan dengan berbagai media pembelajaran salah satunya penggunaan video pembelajaran. Penggunaan video pembelajaran dapat membantu mahasiswa untuk dapat memecahkan masalah belajar. Untuk itu diperlukan kemampuan mahasiswa dalam menganalisis video pembelajaran.

Penggunaan strategi pembelajaran webinar mengkondisikan mahasiswa dan dosen lebih dekat satu sama lain melalui sejumlah teknologi. Strategi pembelajaran webinar telah menjadi strategi yang sangat diperlukan dalam memastikan lingkungan pendidikan online di pendidikan tinggi untuk hubungan yang lebih erat antara mahasiswa dan dosen. Webinar yang awalnya bermula dari seminar web dan kelas online yang dimasa lampau hanya dianggap sebuah kursus online saat ini menjadi terend tersendiri dalam penggunaan strategi pembelajaran di masa pandemi Covid-19 ini.

\section{PENUTUP}

Berdasarkan temuan penelitian mengenai upaya meningkatkan keaktifan mahasiswa dalam menganalisis video pembelajaran melalui strategi pembelajaran webinar dapat disimpulkan bahwa:

1. Terdapat peningkatan keaktifan dosen dalam menggunakan strategi pembelajaran webinar baik pada pada siklus I maupun siklus II dengan rata-rata peningkatan dari siklus I ke ke siklus II sebesar 21.6\%. Perolehan nilai keaktifan dosen pada siklus kedua ini telah mencapai indikator keberhasilan dalam penelitian ini yang berada pada rentang skor $85 \%-100 \%$.

2. Terdapat peningkatan pada keaktifan mahasiswa dalam menganalisis video pembelajaran dengan menggunakan strategi 
pembelajaran webinar baik pada siklus I maupun siklus II dengan rata-rata peningkatan dari siklus I ke ke siklus II sebesar $20.4 \%$. Perolehan nilai keaktifan mahasiswa pada siklus kedua ini telah mencapai indikator keberhasilan dalam penelitian ini yang berada pada rentang skor $75 \%-100 \%$.

3. Terdapat peningkatan pada kemampuan mahasiswa dalam menganalisis video pembelajaran dengan menggunakan strategi pembelajaran webinar baik pada siklus pertama maupun siklus kedua dengan ratarata peningkatan dari siklus I ke siklus II sebesar $33.98 \%$. Perolehan nilai kemampuan mahasiswa dalam mengalisis video pembelajran pada siklus kedua ini telah mencapai indikator keberhasilan dalam penelitian ini yang berada pada rentang skor 70\%-100\%.

Berdasarkan pada kesimpulan hasil penelitian penelitian yang telah dilaksanan, beberapa saran yang dapat diberikan oleh peneliti sebagai berikut:

1. Dosen hendaknya menggunakan strategi pembelajaran yang senantiasa adaptif dengan perkembangan zaman agar mahasiswa dapat lebih aktif dalam menggunakan berbagai media interaktif dalam mengimplementasikan strategi pembelajaran online agar dapat menarik minat dan perhatian mahasiswa untuk dapat meningkatkan dan keaktifan mereka dalam mengikuti matakuliah Pemantapan Kemampuan Mengajar.

2. Mengingat penggunaan strategi pembelajaran webinar ini memerlukan kuota internet yang besar, disarankan kepada penyelenggara pendidikan tinggi dapat membantu mahasiswa untuk memberikan bantuan pembelian kuota internet

3. Untuk peneliti yang lain yang ingin melakukan penelitian lanjut tentang strategi pembelajaran webinar dan peningkatan kemampuan mahasiswa dalam menganalisis video pembelajaran, disarankan agar penelitian yang telah dilaksanakan ini dapat dijadikan sebagai bahan acuan untuk dilaksanakannya penelitian yang lain, baik itu Penelitian Tindakan Kelas, maupun penelitian lainnya karena penelitian ini telah memberikan solusi terhadap permasalahan pembelajaran saat ini.

Dalam proses pembelajaran ada unsur penting yaitu penerapan media. Pemilihan media video memberikan manfaat yang besar dalam penyampaian pesan dalam pembelajaran. Media video merupakan media pembelajaran yang paling tepat dan akurat dalam menyampaikan pesan dan akan sangat membantu pemahaman peserta didik. Dengan adanya media video, peserta didik akan lebih paham dengan materi yang disampaikan pendidik melalui tayangan sebuah film yang diputarkan. Unsur-unsur yang terdapat dalam media video seperti suara, teks, animasi, dan grafik. Dengan adanya media video peserta mampu mencapai kemampuan dalam ranah kognitif, afektif, psikomotorik dan meningkatkan kemampuan interpersonal.

\section{DAFTAR PUSTAKA}

Adnan, Muhammad. \& Anwar, Kainat. (2020). Online Learning Amid the COVID-19 Pandemic: Students' Perspectives. Journal of Pedagogical Sociology and Psychology. Volume 2, Issue 1, 2020. Diakses pada Tanggal 19 September, Dari http://www.doi.org/10.33902/JPSP.

Basilaia, G., \& Kvavadze, D. 2020. Transition to Oline Education in Schools During a SARS-CoV-2 Coronavirus (Covid-19) Pandemic in Georgia. Pedagogical Research, Volume 5 (4).

Bates, A. W. (2015). Teaching in A Digital Age; Guidelines for Designing Teaching and Learning for A Digital Age. Open.Bc Campus. Diakses dari http://opentextbc.ca/teachinginadigitala ge.

Crawford, J. Butler-Henderson, K. Rudolph, J., \& Glowatz, M. (2020). COVID-19: 20 Countries' Higher Education Intra Period Digital Pedagogy Responses. Journal of Applied Teaching and Learning (JALT). Volume 3.(1).

Kay, R. H. (2012). Exploring The Use of Video Podcasts in Education: A Comprehensive Review of The Literature. Computers in Human Behavior, Vol.28, No.3.

Fahrurozi, Slamet Kurniawan. Maryono, Dwi. \& Budiyanto, Cucuk. (2017). The Development of Video Learning to Deliver a Basic Algorithm Learning. Indonesian Journal of Informatics 
Education. Volume 1, Issue 2. Desmber 2017.

Humphrey, R. L. Le Grand, C. S. \& Beard, D. F. (2013). How to Host a Successful Webinar. Journal Strategic Finance. Vol 95. Issue 1.

Harrison, Lauren. (2014). Case Study on the First-time Use of a Webinar by a Small Marketing Firm. Professional Projects from the College of Journalism and Mass Communications. Lincoln:University of Nebraska. Diakses pada Tanggal 19 September, Dari http://digitalcommons.unl.edu/journalis mprojects/1

Kemmis \& Mc. Taggart. (2010). The Action Research Planner. Geelong: Deaken Univercity Press.

Pace, C., Pettit, S. K., \& Barker, K. S. (2020). Best Practices in Middle Level Quaran Teaching: Strategies, Tips and Resources Amidst COVID-19. Becoming: Journal of the Georgia Association for Middle Level Education. 31(1), 2.

Sugiyono (2015). Metode Penelitian Kombinasi (Mix Methods). Bandung: Alfabeta.
Susilawati, Evi. (2017). The Effect of Modeling Learning Strategy and Cooperative Behavior on Civic Education Learning Achievement. Advances in Social Science, Education and Humanities Research, Volume 104.

Susilawati, Evi. (2020). Aplikasi Tutorial Berbantuan Web Untuk Meningkatkan Hasil Belajar Matakuliah Pembelajaran PKn di SD di Tengah Pandemi Covid19. E Prosiding Seminar Nasional Virtual Pendidikan Kewarganegaraan 2020. Penguatan Pendidikan Kewarganegaraan di Indonesia Pada Era Digital. Diakses dari http://C:/SeminarPPKNUNS

Wang, Shiang-Kwei. \& Hsu, Hui-Yin. (2008). Use of the Webinar Tool (Elluminate) to Support Training: The Effects of Webinar-Learning Implementation from Student-Trainers' Perspective. Journal of Interactive Online Learning. Volume 7, Number 3.

Zhong, R. (2020). The Coronavirus Exposes Education's Digital Divide. The New York Times. March, 17. Diakses dari https://www.nytimes.com/2020/03/17/t echnology/china-schoolscoronavirus.html 